\title{
LIÇÕES SOBRE DEMOCRACIA E CIDADANIA A PARTIR DA ANÁLISE DO MOVIMENTO ESCOLA SEM PARTIDO
}

\author{
http://dx.doi.org/10.21527/2176-6622.2018.50.164-182
}

Recebido em: 19/11/2017

Aceito em: 23/10/2018

\section{Camylla Galindo Cezar de Oliveira Silva}

Graduada em Direito - Centro Universitário do Vale do Ipojuca. Graduada em Pedagogia pela Universidade Federal de Pernambuco - Centro Acadêmico do Agreste. Pesquisadora no Projeto de Iniciação Científica: Direitos humanos, violência, e diversidade humana no período ditatorial, no agreste pernambucano (1964-1985). Extensionista no'DHiálogos: Ciclo de debates sobre sociedade e direitos humanos. Pesquisadora do Grupo de Estudos e Pesquisas Interdisciplinares sobre Direitos Humanos (Gepidh-Mércia Albuquerque/Unifavip).camyllagc@gmail.com

\section{Fernando da Silva Cardoso}

Doutorando em Direito - Pontifícia Universidade Católica do Rio de Janeiro, com período sanduíche no CenDoutorando em Direito - Pontificia Universidade Católica do Rio de Janeiro, com periodo sanduiche no Cen-
tro de Estudos Sociais da Universidade de Coimbra, Portugal. Mestre em Direitos Humanos - Universidade Federal de Pernambuco. Especialista em Direitos Humanos - Universidade Federal de Campina Grande. Bacharel em Direito - Centro Universitário do Vale do Ipojuca. Professor assistente, subcoordenador de Pesquisa e Extensão e membro do Núcleo Docente Estruturante do Curso de Direito da Universidade de Pernambuco - Campus Arcoverde. Pesquisador do Grupo de Pesquisas sobre Democracia, Gênero e Direito (PUC-Rio/CNPq), de Educacão em Direitos Humanos, Diversidade e Cidadania (UFPE/CNPq), Movimentos Sociais, Educação e Diversidade na América Latina (UFPE-CAA/CNPq) e do Diversiones - Grupo de Pesquisa sobre Direitos Humanos, Poder e Cultura em Gênero e Sexualidade (UFPE-CNPq). Membro do Núcleo de Estudos e Pesquisas de Educação em Direitos Humanos da UFPE. cardosodh8@gmail.com

\section{RESUMO}

Sob o fundamento de proteção à família e ao direito que pais têm de que seus filhos sejam educados conforme dadas conviç̧ões, o Movimento Escola sem Partido (ESP) expressa em suas proposições legislativas a intolerância, a violência e o combate a uma educação inclusiva, buscando reduzir o ato de educar à mera transmissão de conteúdos alheios a leituras críticas da realidade. Neste estudo analisa-se as perspectivas sobre democracia e cidadania no Movimento Escola sem Partido. Trata-se de uma pesquisa documental, a partir da apreciação de Projetos de Lei (PLS), lidos à luz da análise de conteúdo. O exame dos PLS constata, na primeira categoria analítica, retrocessos à liberdade de cátedra, assim como estratégias retóricas de combate à doutrinação política e ideológica. A defesa da neutralidade pelo ESP opera, na verdade, como um mecanismo de perpetuação da ideologia do Movimento. Na segunda categoria analítica constata-se que os interesses de grupos políticos - apesar de se apontar nos documentos, repetidamente, o pluralismo de ideias - são a tônica dos textos, especialmente quanto ao tolhimento de discussões ligadas à diversidade e à inclusão. Nesta categoria analítica a ausência de reflexão política é traduzida na mera repetição dos conteúdos e dos termos defendidos nos PLs. Por fim, a terceira categoria analítica permite-nos constatar que a cidadania é limitada apenas ao mero direito à informação. O Movimento não reconhece os espaços de formação como construtores de cidadania. A neutralidade proposta pelo ESP, na verdade, opera no esvaziamento do pensamento crítico na educação e na reprodução de desigualdades.

Palavras-chave: Escola sem Partido. Democracia. Cidadania. Liberdade de cátedra.

\section{LESSONS ABOUT DEMOCRACY AND CITIZENSHIP FROM ANALYSIS OF THE MOVIMENTO ESCOLA SEM PARTIDO}

\section{ABSTRACT}

Under the protection of the family and the right of parents to have their children educated according to their convictions, the Movement without a Party (ESP) expresses in its legislative proposals intolerance, violence and the fight against inclusive education, seeking reduce the act of educating to the mere transmission of external contents to critical readings of reality. This study analyzes the perspectives on democracy and citizenship in the Movement without Party School. This is a documentary research, based on the appreciation of Draft Laws, read in the light of content analysis. The examination of the PLs finds, in the first analytical category, setbacks to academic freedom, as well as rhetorical strategies to combat political and ideological indoctrination. The defense of neutrality by ESP operates, in fact, as a mechanism for perpetuating the ideology of the Movement. In the second analytical category it is seen that the interests of political groups - despite repeatedly pointing out the pluralism of ideas - are the emphasis of the texts, especially regarding the avoidance of discussions about diversity and inclusion. In this analytical category, the absence of political reflection is translated into a mere repetition of the contents and terms defended in the PLs. Finally, the third analytical category allows us to see that citizenship is limited to the mere right to information. The Movement does not recognize the spaces of formation as constructors of citizenship. The neutrality proposed by the ESP, in fact, operates in the emptying of critical thinking in the education and reproduction of inequalities.

Keywords: School without party. Democracy. Citizenship. Freedom of the chair.

\section{SUMÁRIO}

1 Introdução. 2 Fundamentação Teórica. 2.1 Educação, Democracia e Cidadania. 2.2 Liberdade de Cátedra e Autonomia Docente: Fundamentos Jurídicos. 2.3 O Movimento Escola sem Partido e os Direitos à Educação e à Liberdade de Cátedra no Brasil. 3 Resultados e Discussões. 3.1 A Análise das Justificativas dos Projetos de Lei do Movimento Escola sem Partido. 3.2 Discussões Sobre Temas Políticos e Transversais nos Espaços de Formação. 3.3 Percepção sobre Democracia e Cidadania nos Projetos de Lei do ESP. 4 Considerações Finais. 5 Referências. 


\section{INTRODUÇÃO}

O Estado Democrático de Direito atribui direitos e deveres aos cidadãos que integram a sua ordem jurídico-política. Numa sociedade democrática a concepção de cidadania está intimamente ligada aos direitos humanos, uma vez que estes podem, em tese, ser invocados diante da violação de direitos inerentes a qualquer cidadão.

Direitos, assim como as obrigações especificadas em lei, para se afirmarem e serem (re)conhecidos por seus titulares, dependem de espaços de formação tanto formais, no sistema de ensino propriamente dito, desde a escola primária até as universidades, como informais, em movimentos sociais, espaços religiosos, Organizações Não Governamentais, partidos, sindicatos, meios de comunicação, entre outros.

Nesse sentido, a educação é um instrumento fundamental para a formação da cidadania. Não se trata, no entanto, de qualquer tipo de educação, mas sim daquela que se revela como um ato político em si, que descontrói a utópica ideia de neutralidade - propícia à perpetuação de sistemas econômicos de opressão, a exemplo do capitalismo, nos quais estão evidenciados como parâmetros a desigualdade e a injustiça social.

A educação que visa à formação da cidadania contribui para o desenvolvimento de pessoas críticas, livres, políticas, democráticas, participativas, criativas, curiosas, capazes de respeitar a diversidade e afirmá-la em seus discursos. Trata-se da possiblidade de se contribuir com o processo de engajamento de sujeitos conscientes, comprometidos com lutas capazes de transformar a realidade social na qual estão inseridos, participando ativamente dos espaços políticos, problematizando as questões sociais, atuando em prol da emancipação humana.

Nesse cenário, a escola desempenha uma função política e social que rompe com a ideia de uma educação voltada ao mero adestramento para o mercado de trabalho, na medida em que se afirma como um instrumento de resistência às violências. Forma-se cidadãos para que superem a lógica do senso comum, uma vez que, conscientes, possam atuar na modificação das práticas e condições sociais que negam ou violam direitos.

Assim sendo, o avanço de práticas que perpetuam o conservadorismo, que buscam silenciar a atuação da escola, ainda que encontrem legitimação, apenas contribuem para o retrocesso à afirmação dos direitos humanos, favorecendo as desigualdades e a injustiça social, uma vez que pretendem a reprodução de conteúdos descontextualizados da realidade social, vazios de conscientização política.

Diante desse contexto e a partir da análise de Projetos de Lei e leis já existentes acerca do Movimento denominado "Escola sem Partido" (ESP), que visa a proibir suposta doutrinação política e ideológica dos educadores em sala de aula, este estudo assume como problema de pesquisa: Quais as perspectivas sobre democracia e cidadania no Movimento "Escola sem Partido"?

Nesse sentido, o objetivo geral proposto consiste em analisar as perspectivas sobre democracia e cidadania no Movimento Escola sem Partido. Os objetivos específicos que nortearam a pesquisa são: investigar se o Movimento Escola sem Partido relaciona em suas propostas o direito à educação e à liberdade de cátedra; relacionar possíveis discursos velados nos Projetos de Lei sobre o Movimento Escola sem Partido quanto à promoção da democracia e da cidadania e, por fim, verificar as repercussões da instituição do Movimento Escola sem Partido para a consolidação de espaços democráticos no Brasil.

Este estudo procura refletir sobre os processos apolíticos que têm buscado, em diversas frentes, retirar dos espaços formativos a gênese da discussão sobre a sua capacidade de contribuir com a reflexão dos fatos sociais. Considera-se que, na verdade, estas propostas têm significado na reprodução do sistema econômico e dos interesses classicistas, revelando-se a insistente subalternização das questões sociais, na perpetuação dos modelos de dominação, seja por meio da política, dos mecanismos ideológicos do Estado ou da economia.

Assim, esta pesquisa presta-se a contribuir na formação continuada daqueles/as que se interessam pela formação em/para os direitos humanos, especialmente em relação a como o Estado afirma o direito à educação, tendo a análise de Projetos de Lei nacionais, estaduais e municipais sobre o Movimento Escola sem Partido. Além disso, o presente trabalho manifesta a preocupação de problematizar questões que não são priorizadas na educação jurídica e de áreas afins, as quais ainda carecem de aprofundamento e debate no espaço das Instituições de Ensino Superior, uma vez que este é um dos ambientes mais plurais de produção científica que poderão ensejar uma ampliação na discussão sobre a necessidade de fazer da escola um meio de produção de conhecimentos voltado à formação humana cidadã e não apenas de reprodução e técnica. 
Por outro lado, a partir desse estudo propõe-se estimular a reflexão sobre o direito à educação e o seu exercício, a partir da compreensão de que a escola deve continuar sendo contexto de transformação social, emancipação humana, de conscientização política e construção do saber crítico. Para tanto, a proposta de discutir questões relacionadas à democracia e cidadania no ambiente escolar, espaço essencial à construção intelectual, crítica e de conscientização política, pressupõe a escola como lócus primário de transformação das bases sociais, de problematização da realidade.

Quanto ao trajeto metodológico, utilizou-se do método dialético de pesquisa (GIL, 2008). Busca-se, com este método, uma interpretação plural da realidade eleita. Esta pesquisa é de caráter qualitativo por nos preocuparmos na leitura do fenômeno, sobretudo em explicá-lo na condição de sentido e significado (CRESWELL, 2010). Os tipos de pesquisa que estruturaram esta pesquisa foram o bibliográfico e exploratório, pesquisas pautadas em estudos e produções científico-teóricas, e o descritivo (GIL, 2008), com vistas à explicitação dos resultados encontrados a partir da análise das perspectivas da democracia e da cidadania dos projetos de lei do ESP. A técnica de coleta de dados foi documental, tendo em vista que a fonte primária desta pesquisa são os Projetos de Lei. A técnica de apreciação dos dados foi a análise de conteúdo (BARDIN, 2011), que auxiliou na categorização dos aspectos implícitos nos Projetos de Lei do Movimento Escola sem Partido.

Em sua estruturação, o estudo parte da discussão teórica sobre educação, democracia e cidadania, apontando os fundamentos jurídicos e as contribuições científicas sobre a liberdade de cátedra e autonomia docente, para então refletir sobre o Movimento Escola sem Partido e sua relação com os direitos à educação e à liberdade de cátedra no Brasil. Em seguida passa-se à discussão dos dados da pesquisa, tendo como fundamento a análise de 20 Projetos de Lei propostos pelo ESP, com vistas a problematizar a dinâmica do Movimento e suas implicações sobre a educação, democracia e cidadania. Por fim, após a análise dos PLs, são apresentadas as considerações finais que sintetizam os resultados da pesquisa, buscando responder à problemática de pesquisa eleita.

\section{FUNDAMENTAÇÃO TEÓRICA}

A princípio é apresentada discussão envolvendo educação, democracia e cidadania, buscando pensar as interseções entre esses campos. Em seguida, partindo de uma concepção de educação voltada à formação consciente em ambientes de participação política e social, destacou-se a liberdade de cátedra como mecanismo essencial na construção de conhecimentos, meio de diálogo e de promoção do desenvolvimento humano. Por fim, é apresentado o Movimento Escola sem Partido, considerando alguns aspectos do Movimento na contramão da perspectiva de educação para a cidadania.

\subsection{Educação, Democracia e Cidadania}

A educação que adota a política de direitos humanos tem como referência a diversificação do aprendizado, na medida em que busca garantir as mesmas oportunidades educacionais, promovendo a autonomia, a solidariedade, a participação e o comprometimento crítico-social. Essa visão educacional pretende consolidar sociedades mais justas, democráticas, igualitárias e cidadãs para todos, sem distinção em razão da raça, ideologia política, classe, religião.

Pensando a educação na perspectiva dos direitos humanos, a democracia é a ordem política adequada ao desenvolvimento dos sujeitos, pois oportuniza um protagonismo fundamental nas tomadas de decisão sobre interesses comuns.

Assim, visando a romper discursos universais e vazios sobre participação, que abarcam uma concepção inócua sobre o fazer democrático, em que há uma leitura de cidadania reduzida ao direito de votar e ser votado, ou que limita cidadãos em seus direitos, sem maiores participações nas ordens política, econômica e social, a educação deve ser um meio de transformação da realidade, que priorize o pensar crítico. Afinal, sujeitos em formação dialogam e refletem a sociedade, a partir de um ensino-aprendizagem contextualizado.

Nesse sentido, nas palavras de Freire (1976), o sujeito deve integrar a realidade de modo a ser capaz de transformá-la, a partir da reflexão. O sujeito integrado não deve se acomodar ou simplesmente se adaptar, deve ser ativo, capaz de modificar a realidade. Para que seja consciente, crítico e capacitado a transformar a realidade social, contudo, a educação deve proporcionar sua participação nos espaços formais, não formais 
ou informais de educação, a sociedade deve ser o ponto de partida dessa prática. Ao ser integrante ativo e participante desses espaços, o sujeito se apropria de direitos e deveres que existem para além dos ambientes de formação, e, uma vez conscientes de que são sujeitos ativos de direitos e deveres, está instruindo o processo de cidadania.

Nessa perspectiva, espaços de formação democrática necessitam adotar uma postura político-pedagógica voltada para a desconstrução das relações autoritárias, fundamentando-se em princípios de participação, formando para a emancipação e crítica, reconhecendo os diferentes sujeitos como o centro do processo educacional, na medida em que devem ser motivados a praticar a democracia

[...] à formação para a tomada de decisões políticas em todos os níveis, pois numa sociedade verdadeiramente democrática ninguém nasce governante ou governado, mas pode vir a ser, alternativamente - e mais de uma vez no curso da vida - um ou outro (BENEVIDES, 1996, p. 226).

Percebe-se, portanto, que a educação democrática propõe-se a desconstruir a ideologia dominante de divisão de classes, quando rompe com o entendimento de que grupos dominantes devem se perpetuar no poder em detrimento de minorias que devem servi-los, ao reconhecer que todos têm iguais condições de serem governantes e governados, participantes das decisões políticas, sujeitos ativos na sociedade.

Para concretizar a educação para a democracia é imprescindível que se reconheça que nenhum sujeito envolvido no sistema educacional é neutro, despolitizado. Ao contrário, o modelo de educação que busca adestrar e reproduzir não se presta à função social desempenhada pela educação democrática. A educação é um instrumento de transformação social. É capaz de formar sujeitos conscientes e não meros reprodutores da ideologia dominante.

Nessa direção, vale mencionar a contribuição de Frigotto:

Se o conhecimento científico tem como fim entender quais as determinações que produzem os fenômenos da natureza e os sociais, em sociedades cindidas em classes sociais com interesses conflitantes e antagônicos, as concepções de natureza e sociedade e de ser humano, os métodos de apreendê-las e os resultados que daí advêm não são neutros e, portanto, são políticos. Vale dizer, que afirmam ou se contrapõem aos interesses de determinada classe ou grupos sociais $(2017$, p. 29).

O autor argumenta que a educação desempenha uma função política, na medida em que seu objetivo não é repassar conteúdos descontextualizados da realidade dos sujeitos que atende. A educação deve se prestar, sobretudo, à emancipação humana. $\mathrm{O}$ ato de educar é livre em essência, deve conduzir estudantes a problematizarem o cotidiano, instigando-os a integrar ativamente os espaços de participação, conscientizando-os do poder que têm de romper com os processos de exploração.

Nesse contexto, todos os conhecimentos, quaisquer que sejam, devem ser valorizados e respeitados, para que as pessoas possam crescer no contato com discussões mais inclusivas relacionadas a minorias, gênero, violência contra a mulher, racismo, etnia, entre outros, dialogando, refletindo, politizando-se, se empoderando, ressignificando a própria prática educativa.

Por mais utópica que possa parecer, essa é a concepção de educação que deve ser buscada. Nas palavras de Gadotti (1992), é aos poucos que se operam as grandes mudanças, resultantes de um esforço contínuo, da luta cotidiana, mudando passo a passo, pacientemente. É a partir do esforço em contextualizar a educação com a realidade social do indivíduo que este se apercebe das relações de opressão, das desigualdades entre as classes, da dicotomia entre dominantes e dominados, tornando-se capaz de atuar, de fazer a escola, verdadeiramente, cidadã. ${ }^{1}$

\footnotetext{
${ }^{1}$ Essa perspectiva apresentada pelo autor é traduzida também na Declaração Universal de Direitos Humanos, que orienta os Estados-membros da ONU a construírem um sentido sobre democracia e direitos humanos voltado à formação de um ser humano tolerante, íntegro, preparado para o convívio com sociedades plurais, partindo de uma educação para o pensamento crítico, propiciando ao sujeito autonomia, dignidade humana, promovendo o respeito pelos direitos humanos, pelas liberdades fundamentais, desenvolvendo plenamente a personalidade humana, conforme dispõe o artigo XXVI da Declaração.
} 
Esse discurso alusivo sobre a educação para a democracia é parte de uma agenda mais ampla em relação ao debate proporcionado a partir das discussões sobre direitos humanos, que têm refletido, principalmente, sobre a liberdade de cátedra, entendendo que esse direito influencia na afirmação da democracia. Afinal, segundo Castro (2010), a preparação educacional que contempla a participação política, a igualdade de condições, o posicionamento crítico, valorando o direito de receber informações, formar opiniões, propõe-se não só à afirmação da personalidade, como ao pleno exercício da cidadania.

\subsection{Liberdade de Cátedra e Autonomia Docente: Fundamentos Jurídicos}

O contexto jurídico brasileiro atribui status constitucional à liberdade de ensinar, de modo que, atrelado ao direito fundamental à educação, está o direito do docente em expressar-se livremente, exercer sua profissão com autonomia e dignidade, como reflexo de sua condição de sujeito de direitos, protegido pela Constituição.

O texto constitucional vai além, atribuindo à educação a missão de preparar para o exercício da cidadania, visando ao pleno desenvolvimento da pessoa, determinando, para tanto, como um dos princípios que devem guiar o ensino no Brasil "a liberdade de ensinar e de divulgar o pensamento, o saber, a arte, o pluralismo de idéias", conforme os artigos 205 e 206 da Constituição Federal (BRASIL, 1988).

Esses princípios, aliados à "liberdade de expressão da atividade intelectual, artística, científica e de comunicação" previstas no artigo 5, IX da Constituição (BRASIL, 1988), fundamentam o direito incontestável do docente à liberdade de cátedra, atentando ao compromisso com uma educação que contribua para a transformação social.

Nesse mesmo sentido, a Lei de Diretrizes e Bases da Educação Nacional, no 9.394/96, assegura em seu artigo 3으. II, "a liberdade de ensinar, de divulgar o pensamento, o saber, a cultura, o pluralismo de idéias", em consonância com o disposto no texto constitucional, ratificando mais uma vez o direito à liberdade de cátedra docente (BRASIL, 1996).

Em que pesem, contudo, as normas anteriormente referenciadas assegurarem a liberdade de ensino, há uma resistência no reconhecimento do referido direito, principalmente quando o docente se propõe a construir um conhecimento livre de amarras religiosas ou ideológicas, manifestando seus posicionamentos e convicções, oferecendo ao sujeito em formação diferentes perspectivas da realidade na qual está inserido.

Nas palavras de Barcellos (2011), a educação tem relevante papel no desenvolvimento e preparo da pessoa para a cidadania, devendo formar para a tomada de decisão consciente em relação ao voto, mas também deve ser o meio pelo qual assimilará direitos mais elementares, tendo uma chance de acesso ao mercado de trabalho e de modificação da sua realidade.

Quando se limita o direito à liberdade de cátedra ao mero direito de exercer a atividade docente, descontextualizada da missão de formar para a cidadania e emancipação humana, em razão do condicionamento e limitação arbitrária das formas de expressividade da autonomia do professor, desassocia-se a liberdade de ensino da liberdade de cátedra, revelando um campo fértil para a mera reprodução de ideias.

Assim, o que se discute aqui não se trata de uma liberdade ilimitada, tendo em vista que o texto constitucional a prevê, mas que esta sofre limitações legítimas pela própria lei, sem ser prejudicada (SILVA, 2010). Todo direito sofre limitações. O perigo reside, contudo, em limitações arbitrárias ao exercício amplo de tais liberdades, como no caso da de cátedra.

Nesse contexto, Bastos e Martins (1998) definem a liberdade de ensino como um pressuposto para o professor atuar conforme as suas convicções, não devendo estar submetido ao que os outros impõem, libertando a educação de manipulações, autoritarismos, e, por conseguinte, garantindo e possibilitando o desenvolvimento da pesquisa e da ciência.

Nas palavras de Mello (1984), a liberdade de cátedra, então, se configura num direito que permite ao professor expressar-se e comunicar seus conhecimentos no exercício da sua função. Constitui-se como direito próprio daquele que exerce a atividade docente. A liberdade de cátedra, no entanto, deve ser considerada não só como um direito, mas como mais umas das responsabilidades do professor, pois é na escolha dos conteúdos, da técnica a ser utilizada, da forma como os conhecimentos serão compartilhados que estará materializando a educação, contribuindo para o exercício da democracia e da cidadania. 
À vista dessa concepção, é importante destacar que as Diretrizes da Organização das Nações Unidas para a Educação, a Ciência e a Cultura (Unesco), organismo integrado à Organização das Nações Unidas, corroboram com o entendimento de que a educação é um direito humano fundamental e é essencial para o exercício de todos os direitos. Assim, a partir do olhar de uma educação de qualidade e inclusiva, a Unesco aponta para a minimização dos índices de pobreza, a integração de grupos minoritários, bem como o contínuo processo de redução da mortalidade infantil, a promoção à equidade da educação e a afirmação do desenvolvimento sustentável, da paz e da democracia ao se educar para a diversidade, premissa reafirmada pelo Relatório para a Unesco da Comissão Internacional sobre educação para o século 21 e na Convenção sobre a proteção e promoção da diversidade das expressões culturais (ORGANIZAÇÃO..., 1996, 2005).

Althusser (1980) afirma que a escola como aparelho ideológico do Estado aduz saberes envoltos à ideologia dominante. E, para atender aos objetivos propostos pela Unesco, o professor não pode ser escravo de um currículo engessado que serve aos interesses de poucos, uma vez que, de acordo com Silva (2013), o currículo está fundamentado na cultura dominante, perpetuando a divisão de classes em que o trabalhador continuará trabalhador e o dono do capital se perpetuará no poder, numa dinâmica basicamente hereditária/ meritocrática.

Entendendo-se o conhecimento como significativo para quem aprende, o professor chegará mais perto de uma educação que se não pode tudo, alguma coisa ela pode, de modo que, se não é por meio dela que ocorrerão as transformações sociais, também ela não atuará simplesmente como meio de reprodução da ideologia dominante (FREIRE, 2000).

Quando o professor tem autonomia, portanto, trabalha com mais liberdade, desenvolve também maior interesse pela prática docente, aperfeiçoa o ensino, ajuda a construir uma sociedade plural em seus valores, crenças e direitos. Supera-se a simples transmissão de conhecimento, na medida em que se passa a construí-lo criticamente, dialogando com o sujeito em processo de formação.

O conhecimento, então, deve ser desenvolvido de forma democrática e construtiva, a partir do respeito ao posicionamento dos professores e dos atores do processo de formação, sendo contemplados os direitos às liberdades de cátedra e à educação, valorizando o diálogo, a autonomia docente e discente, a troca de saberes, o pluralismo de ideias, num espaço que promova a transformação social a partir de uma educação cidadã e participativa.

\subsection{O Movimento Escola Sem Partido e os Direitos à Educação e à Liberdade de Cátedra No Brasil}

O Movimento Escola sem Partido, desde o ano de 2004, vem buscando introduzir nas escolas um modelo de educação segundo o qual os professores devem educar os alunos estritamente embasados nos conteúdos programáticos estabelecidos no currículo escolar. Em outras palavras, o papel do professor deve ser o de repassar aos estudantes apenas os conhecimentos inerentes às disciplinas obrigatórias, sem expressar suas opiniões, sem crítica, sem problematização, sem contextualização.

Fundamentados nessa ideia, os defensores do ESP advogam por uma educação sem doutrinação pois, em seu entendimento, os professores exercem doutrinação sobre seus alunos quando expressam sua opinião e discutem temas relacionados à identidade de gênero, emancipação feminina, racismo, movimentos sociais, manifestações de rua, estudos sobre índios, africanos, direito de greve, entre outros temas afins à realidade social.

A proposta do Movimento é retirar dos ambientes de formação discussões que envolvam convicções morais e de valores, tendo em vista que entendem ser da família a responsabilidade e o direito de educar seus filhos consoante sua própria cultura, crenças, princípios. Para tanto, o ESP fundamenta-se na Convenção Americana sobre Direitos Humanos, especificamente no artigo 12, que aborda o direito à liberdade de consciência e de conservar, mudar, professar e divulgar a religião ou crenças, em público ou em espaços privados, seja individual ou coletivamente.

É direito da família educar seus filhos de acordo com a liberdade individual que cada uma detém, contudo o Movimento Escola sem Partido deturpa esta garantia como estratégia para a retirada do ambiente escolar da discussão de temáticas que remetem ao claro avanço das conquistas sociais em direção à democracia e à igualdade, haja vista que a escola é o palco, por excelência, da desnaturalização das agressões, injustiças, desigualdades. 
Sob o crivo da não ideologização e do apartidarismo, o ESP vem travando uma luta para que a escola retroceda a um ambiente de acriticidade, pregando a ideia de neutralidade como base do discurso. Conforme Manhas (2016), no entanto, ainda quando defende que não deve ser perpetuada certa ideologia, não está fazendo outra coisa senão impondo as suas próprias convicções ideológicas.

Conforme a autora, o ESP argumenta que o professor é mero reprodutor de conteúdos, rompendo com a construção de uma concepção da educação fundamentada como um ato político associado a um ensino vinculado com a realidade, em que se busca, incessantemente, a emancipação humana por meio da consciência, como aduz Fernandes:

Pensar politicamente é alguma coisa que não se aprende fora da prática, se o professor pensa que sua tarefa é ensinar o $A B C$ e ignora a pessoa de seus estudantes e as condições em que vivem, obviamente não vai aprender a pensar politicamente ou talvez vá agir politicamente em termos conservadores, prendendo a sociedade aos laços do passado, ao subterrâneo da cultura e da economia (1989, p. 165).

Em contraste com os preceitos do ESP, Ribeiro (2016) destaca a contribuição de Paulo Freire sobre a importância do pensamento crítico como forma de promoção da inclusão social, de avanços de ordem política e econômica no país. Isso porque é por meio da educação que o sujeito se conscientiza da sua condição de oprimido e, a partir da participação nos espaços políticos, age para a construção de uma sociedade menos desigual. A esta conscientização, segundo Ratier (2016), o ESP dá o nome de proselitismo ideológico.

No Movimento ESP critica-se firmemente a obra freiriana, na medida em que consideram o trabalho de ensinar, defendido por Paulo Freire, como uma tentativa de subversão à ordem econômica, classicista, assim como à ideologia dominante. Esta é uma visão vazia, sobretudo tendo em mente a construção de toda uma obra que combateu quaisquer doutrinações, seja da Igreja ou da educação.

A importância de se discutir questões que perpassam a realidade social dos sujeitos em formação vai além de lutas de partidos políticos, de discussões de valores, posicionamentos religiosos. A discussão, por exemplo, de gênero e sexualidade nas escolas importa para que as diferenças não se transformem em desigualdades, conforme observa Manhas (2016). As desigualdades estão presentes no contexto social brasileiro, isto é um fato, contudo "as injustiças vêm cada vez sendo mais desnaturalizadas na consciência social, que reivindica agora não somente o acesso aos direitos humanos, como também qualidade e equidade a esse respeito" (RIBEIRO, 2016, p. 7).

Nesse cenário, o professor tem um papel fundamental como ser social e político que usa a educação como instrumento de luta. Usurpar sua liberdade de cátedra implica silenciar a escola diante das desigualdades, esvaindo esse ambiente de aspirações democráticas, limitando o papel de formador de cidadãos. Nas palavras de Frigotto (2016, p. 4), "Decreta-se a idiotização dos docentes e dos alunos, autômatos humanos a repetir conteúdos que o partido único, mas que se diz sem partido, autoriza a ensinar".

Nessa medida, o ESP faz apologia a um país totalitarista no qual não se discute questões políticas, sociais, econômicas, em que a ausência de criticidade formaliza um ambiente propício à técnica burocrática, haja vista que a (suposta) neutralidade defendida pressupõe um posicionamento político de aceitação e reprodução dos interesses da ideologia dominante. A esse respeito, Frigotto $(2016$, p. 2) destaca que: "Os arautos e mentores da "Escola sem Partido" avançam num território que historicamente desembocou na insanidade da intolerância e eliminação de seres humanos sob o nazismo, o fascismo e similares".

O Movimento Escola sem Partido reflete mais uma tentativa, camuflada, de legitimar, mediante Projetos de Lei, práticas abusivas que enaltecem a discriminação, desigualdades, intolerâncias, e ameaçam a liberdade e a democracia, escondidas atrás da ideologia da "liberdade" dos pais e alunos contra a doutrinação nas escolas. Segundo Frigotto (2016, p. 4), a "pedagogia de confiança e diálogo é substituída pelo estabelecimento de uma nova função para alunos, pais, mães: dedo-duro. Muito mais grave do que os vinte e um anos de ditadura civil-militar onde os dedo-duro eram profissionais".

Dessa forma, o que se percebe é o descaso que o ESP apresenta com a educação, diante de um manejo político que reflete unicamente a intenção de evitar a discussão de determinados conteúdos em sala de aula, usando os pais como escudo para sua luta e criminalizando os educadores que buscam a formação cidadã 
de seus alunos, abordando em aula temáticas contextualizadas com a realidade, na busca de formar pessoas comprometidas com a transformação da sociedade na medida em que são sujeitos críticos que lutam pela emancipação humana.

Assim, cumpre inferir os discursos velados nos Projetos de Lei do ESP quanto à promoção da democracia e da cidadania, tendo em vista que este Movimento apresenta propostas absurdas e letais, tanto pelo que manifestam como pelo que escondem, como preconiza Frigotto (2016).

\section{RESULTADOS E DISCUSSÕES}

A partir da análise dos Projetos de Lei (PLs) do Movimento Escola Sem Partido, foram eleitas três categorias analíticas que dialogam com a fundamentação teórica desta pesquisa, a saber:

1. CATEGORIA ANALítiCA 1: Análise das justificativas dos Projetos de Lei do Movimento Escola Sem Partido.

2. CATEGORIA ANALÍTICA 2: Discussões sobre temas políticos e transversais nos espaços de formação, a partir do ESP.

3. CATEGORIA ANALÍTICA 3: Percepção sobre democracia e cidadania nos PLs do ESP.

Para uma melhor compreensão da análise dos dados e sua consequente discussão, foram elaborados três quadros, cada um deles dividido em três colunas. Na primeira coluna constam as Categorias Analíticas anteriormente descritas, na segunda coluna as Unidades de Registro e na terceira as Unidades de Contexto. Considerando essa representação, foram extraídos trechos da justificação e do texto normativo dos PLs para subsidiar o debate sobre o Movimento Escola sem Partido.

\subsection{A Análise das Justificativas dos Projetos de Lei do Movimento Escola Sem Partido}

Das justificativas dos PLs do ESP pode-se perceber algumas compreensões latentes sobre a liberdade de cátedra nos textos, além de ser possível entender o disfarce no discurso de combate à doutrinação política e ideológica, bem como discutir que a neutralidade defendida pelo ESP funciona na realidade como uma ferramenta de perpetuação da ideologia do Movimento. Essas percepções estão elencadas na tabela a seguir, acompanhadas de extratos dos PLs reproduzidos nas unidades de contexto:

Tabela 1 - Análise das justificativas dos Projetos de Lei do Movimento Escola sem Partido

\begin{tabular}{|c|c|c|}
\hline $\begin{array}{l}\text { ANÁLISE DE } \\
\text { CONTEÚDO }\end{array}$ & \multicolumn{2}{|c|}{$\begin{array}{l}\text { PL 2974/2014; PL 193/2016; PL 250/2014; PL 69/2015; PL 960/2014; PL 53/2015; PL } \\
\text { 293/2014. }\end{array}$} \\
\hline $\begin{array}{l}\text { CATEGORIA } \\
\text { ANALITICA }\end{array}$ & $\begin{array}{l}\text { UNIDADE DE } \\
\text { REGISTRO }\end{array}$ & UNIDADE DE CONTEXTO \\
\hline $\begin{array}{l}\text { A ANÁLISE DAS } \\
\text { JUSTIFICATIVAS DOS } \\
\text { PROJETOS DE LEI } \\
\text { DO MOVIMENTO } \\
\text { ESCOLA SEM } \\
\text { PARTIDO }\end{array}$ & $\begin{array}{c}\text { Compreensões } \\
\text { latentes sobre } \\
\text { a liberdade de } \\
\text { cátedra nos textos } \\
\text { dos PLs }\end{array}$ & $\begin{array}{l}\text { PL 2974/2014; PL 193/2016; PL 250/2014; PL 69/2015; PL } \\
\text { 960/2014; PL 53/2015: "Ora, é evidente que a liberdade de } \\
\text { aprender e a liberdade de consciência dos estudantes restarão } \\
\text { violadas se o professor puder se aproveitar de sua audiência } \\
\text { (literalmente) cativa para promover em sala de aula suas próprias } \\
\text { concepções políticas, ideológicas e morais" (grifos nossos). } \\
\text { PL 293/2014: "O que se espera com a publicidade desta lei, é é } \\
\text { a busca pelo respeito aos direitos fundamentais de cada aluno, } \\
\text { garantidos pela Carta Magna, entre eles, o Direito de Livre } \\
\text { Consciência e respeito à Cultura da Família, buscando limitar } \\
\text { a atuação dos educadores apenas ao exercício de aplicação do } \\
\text { conteúdo escolar, ou seja, aterem-se à ciência para qual foram } \\
\text { formados" (grifos nossos) }\end{array}$ \\
\hline
\end{tabular}




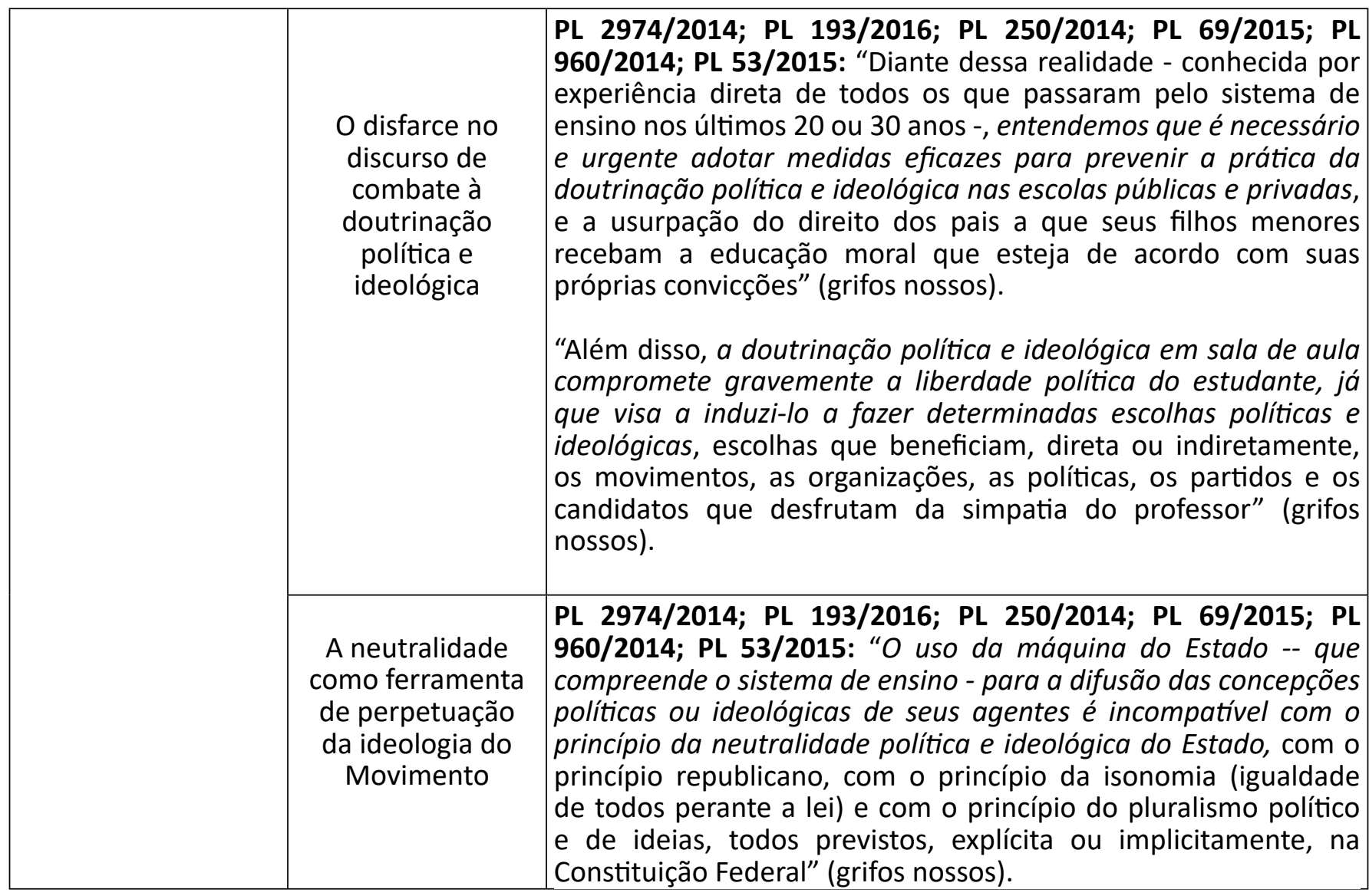

Fonte: Dados provenientes da pesquisa.

A princípio, cumpre destacar as compreensões latentes sobre a liberdade de cátedra nos textos dos PLs, ressaltando que em nenhum PL aparece qualquer garantia que o docente possa ter de exercer sua atividade, o que contraria o direito constitucional à liberdade de cátedra do professor e do exercício da sua função. Sem embargo, o que se percebe é a tentativa de limitar arbitrariamente a atividade docente, revelando o cunho essencialmente político do Movimento em suas propostas legislativas.

Nesse sentido, Bárbara, Cunha e Bicalho (2017, p. 108) sinalizam que o ESP objetiva promover o silenciamento dos professores, colocando-os "no lugar do elemento perigoso, que precisa ser contido, calado e 'amordaçado' para não ameaçar e contrariar a liberdade de consciência e de crença dada pela educação familiar.". Esse direcionamento, contudo, é apenas aos professores das escolas públicas, tendo em vista que o parágrafo $1^{\circ}$ do artigo 3을 do Anteprojeto de Lei exclui, não coincidentemente, as escolas privadas e confessionais.

A análise dos dados, portanto, permite inferir que o Movimento evidencia a liberdade de aprender e a liberdade de consciência dos estudantes, em detrimento do pluralismo de ensino, justificando que o professor se aproveita dos espaços de formação para promover suas próprias conviç̧ões ideológicas, morais e políticas, restando clara a negação à liberdade de cátedra dos docentes, pois os textos dos PLs, além de silenciarem sobre tal liberdade, constroem a norma voltada a impor deveres aos professores com o objetivo de fazê-los reprodutores de conhecimento. Nessa perspectiva:

O ensino deve ser plural. Pluralismo não significa não ter nenhuma opinião, não tomar partido. Significa ter um ponto de vista e dialogar com outros pontos de vista. Quanto mais debate político, quanto mais reflexão crítica, mais se torna possível o equilíbrio e a pluralidade de opiniões. A liberdade de ensino dos professores, assegurada pela Constituição e pela LDB, e a autonomia da escola, ainda em construção, contribuem para a edificação de uma sociedade plural e democrática (GADOTTI, 2016, p. 156-157).

Desconsiderando que o docente pode expressar suas conviç̧ões, o Movimento não só castra a autonomia e a liberdade do professor, mas também tenta desassociar o sujeito político do ser profissional, constrangendo o formador a exercer um papel atípico à sua função quando o compele a repetir conteúdos dissociados 
da realidade social. O ESP, em um de seus livros, rompe com a ideia de que o professor é um educador, o professor é reprodutor de conteúdos, segregando, assim, o ato de educar e ensinar, pois o professor mecanicamente deve repassar os conteúdos sem contexto, crítica ou problematização (MANHAS, 2016).

Esta concepção fica ainda mais evidente a partir na análise do PL 293/2014, que busca "limitar a atuação dos educadores apenas ao exercício de aplicação do conteúdo escolar", devendo somente proferir os ensinamentos afetos à ciência de formação desses profissionais. Ora, a reprodução de conteúdos esvaídos de contextualização em nada contribui para a formação do sujeito para a cidadania, uma vez que a missão educacional é contribuir para a transformação social, formando sujeitos críticos, capazes de refletir e intervir positivamente e construtivamente na sociedade em que vivem.

Impossibilitado de cumprir com esta missão, diante das limitações impostas pelo Movimento, o professor tem sido exposto ao discurso de combate à doutrinação política e ideológica que nada mais é do que um disfarce para a propagação da luta em causa própria do ESP. Sob o argumento de usurpação do direito que os pais têm de educar seus filhos conforme os seus próprios preceitos, o Movimento repele a chamada doutrinação tendo em vista o desinteresse de que os sujeitos em processo de formação tomem consciência das possibilidades que têm de não se submeterem a uma determinada ordem política e econômica.

Freire argumenta que "O homem não pode participar ativamente na história, na sociedade, na transformação da realidade se não for ajudado a tomar consciência da realidade e da sua própria capacidade para a transformar. [...] Ninguém luta contra forças que não entende" (1977, p. 48).

Este combate à doutrinação está a serviço tão somente das próprias convicções do Movimento Escola sem Partido em perpetuar seus interesses políticos e ideológicos. Assim, os dados da pesquisa revelam que ao afirmar que a doutrinação compromete a liberdade política do estudante, o professor irá induzi-lo a escolher partidos, candidatos, movimentos, organizações pelas quais tem simpatia. Fica demonstrado o receio do Movimento de que essas escolhas conflitem com os partidos que o ESP representa, pois, como será visto mais à frente, o Movimento representa os interesses de determinados grupos políticos.

Outra ferramenta para a perpetuação da própria ideologia do Movimento é o discurso de neutralidade apresentado logo no primeiro artigo dos PLs, além de ser objeto da justificava destes. Na condição de sujeitos racionais, pensantes, entretanto, somos sujeitos políticos por natureza, de modo que não há neutralidade em qualquer que seja o discurso, muito menos quando envolve política, ideologia e educação. Conforme Manhas (2016, p. 18), "Não existe neutralidade, quando defendem a "não ideologização" também estão impregnados de ideologia baseada nas visões de mundo".

loschpe (2008), adepto do Movimento, explica que as aulas devem ser politicamente neutras, da mesma forma que o Estado é laico, em razão de que o aluno e o professor estão em uma relação desigual, na medida em que se o aluno fizer objeções ao docente, poderá sofrer represálias, sendo o inverso impossível, contudo todo ser é dotado de crenças, opiniões, opções políticas, inserido em uma conjuntura cultural e, portanto, distante da neutralidade.

Quando o professor compartilha suas convicções com os sujeitos em formação não significa que estes precisem concordar com todas as opiniões do docente, pelo contrário, a discordância é o que constrói o saber, na medida em que gera discussões, desconstruções e a consequente formação não só de conhecimento, mas também de um sujeito crítico, que pensa e expressa suas próprias visões de mundo.

Essa divergência de opinião, todavia, não deve legitimar quaisquer sujeitos que tenham um desafeto pelo profissional da educação, de forma a mover o Judiciário para denunciá-lo como herege, tal como ocorria nos tempos da Inquisição. Destaca-se que, com o objetivo de combater a chamada doutrinação exercida pelos professores, o Movimento Escola sem Partido disponibiliza em seu site um modelo de notificação extrajudicial, afirmando ser esta uma arma da família contra a doutrinação nas escolas, além de ter criado uma "Associação Escola sem Partido" para os pais acionarem o Judiciário nos casos que julguem de maior relevância. Configura-se, dessa forma, um retrocesso, ao desestimular a democracia nos espaços de formação quando limita a liberdade de cátedra dos profissionais da educação.

\subsection{Discussões Sobre Temas Políticos e Transversais nos Espaços de Formação}

A análise dos dados conduz à compreensão de que o Movimento se presta apenas às questões que envolvem o jogo político, buscando intervir nos espaços de formação com o único objetivo de limitar a atuação dos professores em conquistar mais votos para este ou aquele partido político, como se esta fosse uma prática 
recorrente de todos os docentes, ou ainda como se o professor estivesse apenas a serviço de campanhas político-partidárias. Assim, nesta categoria analítica discutiu-se a importância do diálogo sobre temas que ultrapassam o debate meramente político, tais como ideologia de gênero, sexualidade, etnia, raça, considerando que são temas fundamentais para a formação do sujeito.

Tabela 2 - Discussões sobre temas políticos e transversais nos espaços de formação

\begin{tabular}{|c|c|c|}
\hline $\begin{array}{l}\text { ANÁLISE DE } \\
\text { CONTEÚDO }\end{array}$ & \multicolumn{2}{|c|}{$\begin{array}{c}\text { PL 2974/2014; PL 193/2016; PL 250/2014; PL 69/2015; PL 960/2014; PL 53/2015; PL 293/2014; } \\
\text { PL 102/2016; PL 823/2016; PL 91/2014; PL 7180/2014. }\end{array}$} \\
\hline CATEGORIA ANALÍTICA & $\begin{array}{l}\text { UNIDADE DE } \\
\text { REGISTRO }\end{array}$ & UNIDADE DE CONTEXTO \\
\hline \multirow[t]{3}{*}{$\begin{array}{l}\text { DISCUSSÕES SOBRE } \\
\text { TEMAS POLITICOS } \\
\text { E TRANSVERSAIS } \\
\text { NOS ESPAÇOS DE } \\
\text { FORMAÇÃO }\end{array}$} & $\begin{array}{l}\text { O partido do } \\
\text { Movimento Sem } \\
\text { Partido e sem } \\
\text { educação }\end{array}$ & $\begin{array}{l}\text { PL 2974/2014; PL 193/2016; PL 250/2014; PL 69/2015; PL 960/2014; } \\
\text { PL 53/2015: "A prática da doutrinação política e ideológica nas escolas } \\
\text { configura, ademais, uma clara violação ao próprio regime democrático, } \\
\text { na medida em que ela instrumentaliza o sistema público de ensino com } \\
\text { o objetivo de desequilibrar o jogo político em favor de determinados } \\
\text { competidores" (grifos nossos). } \\
\text { "Artigo 3o/5o - No exercício de suas funções, o professor: } \\
\text { I- não abusará da inexperiência, da falta de conhecimento ou da imaturidade } \\
\text { dos alunos, com o objetivo de cooptá-los para esta ou aquela corrente } \\
\text { político-partidária" (grifos nossos). }\end{array}$ \\
\hline & $\begin{array}{l}\text { O Movimento que } \\
\text { defende o pluralismo } \\
\text { de ideias x O } \\
\text { Movimento que tolhe } \\
\text { a discussão de temas } \\
\text { transversais nos } \\
\text { espaços de formação. }\end{array}$ & $\begin{array}{l}\text { PL 2974/2014; PL 193/2016; PL 250/2014; PL 69/2015; PL 960/2014; PL } \\
\text { 53/2015; PL 293/2014; PL 102/2016; PL 823/2016; PL 91/2014: "Artigo } \\
\text { 10/20 - Fica criado, no âmbito do sistema estadual de ensino, o "Programa } \\
\text { Escola sem Partido", atendidos os seguintes princípios: } \\
\text { II - pluralismo de ideias no ambiente acadêmico" (grifos nossos). } \\
\text { PL 7180/2014: "Art. 3o [...] XIII - respeito às convicções do aluno, de seus } \\
\text { pais ou responsáveis, tendo os valores de ordem familiar precedência sobre } \\
\text { a educação escolar nos aspectos relacionados à educação moral, sexual } \\
\text { e religiosa, vedada a transversalidade ou técnicas subliminares no ensino } \\
\text { desses temas". (AC) (grifos nossos). }\end{array}$ \\
\hline & $\begin{array}{l}\text { A ausência de } \\
\text { reflexão traduzida na } \\
\text { repetição dos PLs }\end{array}$ & $\begin{array}{l}\text { PL 2974/2014; PL 250/2014; PL 69/2015; PL 960/2014; PL 53/2015; PL } \\
\text { 293/2014; PL 102/2016; PL 91/2014: "Artigo } 20 \text { - É vedada a prática de } \\
\text { doutrinação política e ideológica em sala de aula, bem como a veiculação, } \\
\text { em disciplina obrigatória, de conteúdos que possam estar em conflito } \\
\text { com as convicções religiosas ou morais dos estudantes ou de seus pais ou } \\
\text { responsáveis". }\end{array}$ \\
\hline
\end{tabular}

Fonte: Dados provenientes da pesquisa.

Conforme discutido na categoria anterior, a pretexto da violação dos princípios da neutralidade política e ideológica do Estado, da isonomia, do pluralismo político e de ideias e do princípio republicano, os dados apontam que o ESP tenta impor sua própria ideologia, demonstrando que a preocupação do Movimento é muito mais com a política do que efetivamente com os alunos ou seus familiares.

Manipulando a semântica dos conceitos, conforme explica Frigotto (2017, p. 31), o Escola sem Partido na verdade busca promover o

[...] partido da intolerância com as diferentes ou antagônicas visões de mundo, de conhecimento, de educação, de justiça, de liberdade; partido, portanto, da xenofobia nas suas diferentes facetas: de gênero, de etnia, da pobreza e dos pobres, etc. Um partido que ameaça os fundamentos da liberdade e da democracia.

Assim, diante da manifesta preocupação do Movimento com o desequilíbrio que o jogo político sofre com aquilo que eles chamam de "doutrinação", sob o argumento de que os professores favorecem direta ou indiretamente determinados grupos políticos, sem qualquer preocupação efetiva com os sujeitos em processo de formação, o Movimento institui o texto de seus PLs com diversas proibições infundadas aos professores, entre elas a de não fazer cooptação político-partidária ou ideológica. Faz-se mister, portanto, contextualizar os partidos, e seus respectivos representantes, envolvidos nesse Movimento. 
Entre 2004 e 2014 o Movimento manteve-se aparentemente sem atividades, contudo voltou à tona em 2014, após a apresentação de dois Projetos de Lei pelos filhos do então deputado federal Jair Bolsonaro (PSC), o primeiro no Estado do Rio de Janeiro, pelo deputado Flávio Bolsonaro (PL 2.974/2014) e o segundo no município do Rio de Janeiro pelo vereador Carlos Bolsonaro (PL 867/2014).

Ainda em 2014 foi apresentado em âmbito nacional o PL 7180/2014 pelo deputado Erivelton Santana (PSC-BA), sem a bandeira do ESP, mas visando a incluir a ideia de que as convicções dos alunos, pais e responsáveis deveriam ser respeitadas, resguardando a estes o debate sobre educação religiosa, moral e sexual (BRAIT, 2016).

Em 2015 o deputado Izalci Lucas Ferreira (PSDB-DF), envolvido em esquema de desvios de recursos públicos do programa DF Digital, apresentou o PL 867/2015, visando a incluir na Lei de Diretrizes e Bases da Educação (LDB) os pressupostos do Movimento Escola sem Partido.

Também estão entre os defensores do ESP integrantes da bancada evangélica, como João Campos (PSDB-GO), Magno Malta (PR-ES), este último autor do PL 193/2016, que também visa a incluir o ESP na LDB. Ademais pode-se citar o deputado federal Rogério Marinho (PSDB-RN), que prioriza uma educação voltada à profissionalização para o mercado de trabalho, em que a qualificação e o alto nível de produtividade são incentivados (BRAIT, 2016).

O que se pode perceber, portanto, é a latente ideologia e partidarismo refletidos nos perfis dos políticos que defendem as bandeiras do Movimento. De acordo com Sakamoto (2016) e Espinosa e Queiroz (2017), há um predomínio de partidos de direita e de centro envolvidos nas propostas dos projetos de lei, tendo como partido de maior representatividade o PSC, destacando ainda que dos 19 projetos apresentados, 11 dos proponentes são vinculados a alguma igreja. Vale mencionar também que cinco dos projetos de lei foram apresentados pelo PSC, seguidos de quatro projetos apresentados pelo PMDB e PSDB, cada, e um projeto de cada um dos seguintes partidos: PDT, PEN, PP, PRB, PSB e PTN (RATIER, 2016).

Assim, para consolidar a compreensão de que efetivamente o objeto dos PLs é claramente político, destaca-se a seguinte passagem do PL 293/2014, que afirma ser uma prática comum "quando educadores em período eleitoral influenciam ou pedem voto aos alunos para os seus candidatos e é notório a todos, que se trata de uma proibição legal", e continua afirmando que "esse apoio pode influenciar não só os estudantes, mas também a família dos alunos".

Este é um dos aspectos que apontam a contradição do Movimento, pois este milita sob a bandeira de defender o direito dos pais de que seus filhos tenham uma orientação conforme os princípios familiares, todavia o PL anteriormente mencionado demonstra novamente que a luta não é pela família, e sim pela quantidade de votos que o docente atrai com a sua "doutrinação", vedando, portanto, ao professor, a utilização de sua disciplina "como instrumento de cooptação política e ideológica" conforme dispõe, por exemplo, o PL 823/2016.

Além desse aspecto, pode-se extrair dos PLS outra contradição expressa no que diz respeito ao Movimento que defende o pluralismo de ideias ser o mesmo que tolhe a discussão de temas transversais nos espaços de formação. $\mathrm{O}$ artigo 1ㅇ, II, dos PLs assegura o "pluralismo de ideias no ambiente acadêmico", contudo proíbe taxativamente ao professor discutir "aspectos relacionados à educação moral, sexual e religiosa, vedada a transversalidade ou técnicas subliminares no ensino desses temas", tal como se infere do artigo 3으, XIII, do PL 7.180/2014.

Dialogando com Mattos et al. (2017, p. 94), percebe-se que o maior inimigo a ser combatido pelos pais e alunos é o discurso de gênero e sexualidade nos espaços de formação: "pretende-se inviabilizar e mesmo criminalizar todas as iniciativas educativas propostas por professoras e professores que abordem temas como desigualdades de gênero, diversidade sexual (na escola e na sociedade), o combate ao preconceito, ao sexismo e à LGBTfobia".

Note-se, contudo, que a ausência de debate sobre política, gênero, raça, etnia, sexualidade, tem como finalidade perpetuar desigualdades históricas presentes na educação brasileira, tais como crianças e adolescentes negros que tendem a ser mais excluídos da escola, crianças da cidade que frequentam mais a escola do que as do campo ou as com deficiência, ou ainda escolas situadas em locais mais carentes tenderem a oferecer uma educação de qualidade inferior (CARREIRA, 2016). Sobretudo o que é pior na falta de diálogo sobre 
esses temas transversais é a tentativa de fazer com que o indivíduo, único ator político que pode modificar a realidade, aceite com naturalidade essas e outras desigualdades, na hipótese de formado para ser neutro, conforme preconiza o ESP.

Assim, a educação é um meio de disseminar as aspirações democráticas, quando ultrapassa a mera transmissão de conhecimentos. A escola, portanto, é o ambiente mais propício para o debate das questões da realidade social das crianças e jovens, e temas como a diversidade, identidade de gênero, racismo, violência contra a mulher, política, devem fazer parte do contexto escolar, uma vez que ausentes causam efeitos negativos, pois os alunos não se matriculam, reprovam, abandonam a escola tendo em vista a pouca atratividade que ela representa na medida em que não está apta a atender e compreender o universo dos alunos (FREITAS, 2016).

Resta clara, portanto, a suposta tentativa de retirar dos espaços de formação não só a combatida prática da doutrinação, mas também a tentativa de silenciar os docentes e o que é mais perigoso, educar uma geração acrítica, que não consegue enxergar as lutas sociais que estão em seu entorno, revelando-se incapazes de se perceberem numa situação de vulnerabilidade diante da ideologia dominante e, como conseqüência, inaptos a transformarem a realidade da sociedade na qual estão inseridos, reforçando os padrões de dominação, educando-se tal como enseja o deputado Rogério Marinho (PSDB-RN), como mera mão de obra do mercado de trabalho (BRAIT, 2016), traduzindo uma educação servil e alienada.

Outra crítica ao ESP que merece destaque reside na ausência de reflexão traduzida na repetição dos PLs, pois a grande maioria dos projetos que tramitam nas Câmaras e Assembleias Legislativas reproduzem o mesmo texto normativo do PL 2.974/2014 e do PL 867/2014. Isso ocorre porque o Movimento disponibiliza-os em seu site na Internet como modelo que pode ser acessado por qualquer vereador ou deputado interessado nas diretrizes do ESP, denotando que não existe um processo de debate, tampouco de discussão ou aprimoramento, sequer de reflexão sobre o que está sendo proposto, tendo em vista a impossibilidade de todas as Secretarias discutirem ao mesmo tempo esses projetos.

Com essa mera reprodução, os PLs não levam em consideração a realidade dos cidadãos que estão sendo afetados por tal legislação, aplicando indistintamente os Projetos a regiões mais e menos desenvolvidas, metropolitanas ou de interior, urbanas ou rurais, sem demonstrar a menor preocupação em analisar se os PLs atendem às necessidades locais dos indivíduos por eles atingidos.

Reflexo das repetições textuais, sem qualquer processo de debate, pode ser percebido no PL 823/2016, que copia texto de lei erroneamente, a contrário senso do que preconiza o ESP. Conforme o artigo 5o do referido $\mathrm{PL}$, que, no momento de reproduzir o texto normativo, o deputado Cleiton Collins (PP) suprime a negativa (o termo "não") das práticas anteriormente transcritas, tal como recomenda o ESP, de modo que, da forma como está expresso no PL 823/2016, o professor poderia atuar livremente favorecendo ou prejudicando os alunos em razão de suas conviç̧ões, por exemplo.

Este é apenas mais um argumento que retrata as inconsistências de um Movimento que, com base em argumentos de defesa da família, apenas revela os próprios interesses em perpetuar as convicções políticas e ideológicas de determinados grupos políticos, descompromissados com a educação e com os sujeitos em processo de formação.

\subsection{Percepção Sobre Democracia e Cidadania nos Projetos de Lei do ESP}

É explícita a falta de afinidade do Movimento com a realidade dos espaços de formação, perceptível nas limitações que demonstram aos ideais de democracia e cidadania, não reconhecendo esses espaços como propícios à formação de um sujeito capaz de intervir na sociedade, transformando a realidade que o circunda a partir do conhecimento construído crítica e reflexivamente no intuito de contribuir para a emancipação do indivíduo.

Assim, nesta categoria analítica, percebeu-se que a cidadania é limitada apenas ao mero direito à informação, bem como constatou-se que o Movimento não reconhece os espaços de formação como contextos de construção de cidadania, além de ser evidente que a neutralidade dos professores resulta em campo fértil à reprodução de ideologias dominantes. 
Tabela 3 - Percepção sobre democracia e cidadania nos PLs do ESP

\begin{tabular}{|c|c|c|}
\hline ANÁLISE DE CONTEÚDO & \multicolumn{2}{|c|}{ PL 2974/2014; PL 193/2016; PL 250/2014; PL 69/2015; PL 960/2014; PL 53/2015; PL 293/2014. } \\
\hline CATEGORIA ANALÍTICA & UNIDADE DE REGISTRO & UNIDADE DE CONTEXTO \\
\hline \multirow{3}{*}{$\begin{array}{l}\text { PERCEPÇÃO SOBRE } \\
\text { DEMOCRACIA E } \\
\text { CIDADANIA NOS PLS DO } \\
\text { ESP }\end{array}$} & $\begin{array}{l}\text { O Movimento que não } \\
\text { reconhece os espaços } \\
\text { de formação como } \\
\text { espaços de construção } \\
\text { de cidadania }\end{array}$ & $\begin{array}{l}\text { PL 2974/2014; PL 69/2015; PL 960/2014; PL 53/2015: “Art. 40. Os } \\
\text { conteúdos morais dos programas das disciplinas obrigatórias deverão } \\
\text { ser reduzidos ao mínimo indispensável para que a escola possa cumprir } \\
\text { sua função essencial de transmitir conhecimento aos estudantes" (grifos } \\
\text { nossos). }\end{array}$ \\
\hline & $\begin{array}{l}\text { A cidadania limitada ao } \\
\text { direito à informação }\end{array}$ & $\begin{array}{l}\text { PL 2974/2014; PL 193/2016; PL 250/2014; PL 69/2015; PL 960/2014; } \\
\text { PL 53/2015: "Nesse sentido, o projeto que ora se apresenta está em } \\
\text { perfeita sintonia com o art. 2o da Lei de Diretrizes e Bases da Educação } \\
\text { Nacional, que prescreve, entre as finalidades da educação, o preparo do } \\
\text { educando para o exercício da cidadania. Ora, o direito de ser informado } \\
\text { sobre os próprios direitos é uma questão de estrita cidadania" (grifos } \\
\text { nossos). }\end{array}$ \\
\hline & $\begin{array}{l}\text { Professores neutros, } \\
\text { alunos alienados: } \\
\text { um campo fértil } \\
\text { para reprodução de } \\
\text { ideologias dominantes }\end{array}$ & $\begin{array}{l}\text { PL 293/2014: O presente Projeto visa a inibir práticas inadequadas de } \\
\text { atuação de alguns professores em sala de aula no desempenho de suas } \\
\text { funções, que de forma intencionada procuram inculcar nos alunos, } \\
\text { ideologias sobre temas relacionados à política, valores morais, à religião } \\
\text { com o objetivo de que eles influenciem a sociedade (grifos nossos). }\end{array}$ \\
\hline
\end{tabular}

Fonte: Dados provenientes da pesquisa.

Antes de adentrar à análise propriamente dita dos PLs, importa destacar um trecho da interpretação de um dos seguidores do ESP, em um texto disponibilizado na Revista Veja, edição 2.074, 20 de agosto de 2008, referente a uma pesquisa realizada pela Unesco sobre a finalidade da educação:

Quando instado, em pesquisa da Unesco, a apontar as finalidades mais importantes da educação, o professorado brasileiro disse o seguinte: com $72 \%$ dos votos, a campeã foi "formar cidadãos conscientes". A segunda mais lembrada foi "desenvolver a criatividade e o espírito crítico" (60,5\%). Lá atrás, na rabeira, apareceram "proporcionar conhecimentos básicos" (8,9\%) e "transmitir conhecimentos atualizados e relevantes" (17\%). No mesmo levantamento, $73 \%$ dos professores concordaram com a afirmação que segue: "O professor deve desenvolver a consciência social e política das novas gerações". [...] A pesquisa CNT/Sensus publicada nesta edição corrobora esse quadro: só $18 \%$ dos professores da escola pública dizem que seu discurso em sala de aula é politicamente neutro. Setenta e quatro por cento escolhem "formar cidadãos" como missão do professor - apenas 8,4\% dizem que é "ensinar a matéria" (grifos nossos) (IOSCHPE, 2008).

Este texto está disponibilizado no site do Movimento e revela por meio das expressões grifadas que a missão de formar cidadãos não deve estar sobreposta à transmissão de conhecimentos, à promoção de conhecimentos básicos, ao mero ensino da matéria. Nesse sentido, os PLs corroboram com a concepção de que o Movimento não reconhece os espaços de formação como locais de construção de cidadania, uma vez que o texto normativo reconhece que a escola e o professor têm como função essencial a transmissão de conhecimentos, conforme se percebe nesse excerto do PL 1.411/2015, a saber: "É vil a utilização da hipossuficiência intelectual por parte do professor, que goza da inteira confiança do aluno e de sua família para transmitir conhecimentos, para promover sua agenda ideológica pessoal" (grifos nossos).

Assim, os dados mostram que quando o Movimento normatiza que "os conteúdos morais dos programas das disciplinas obrigatórias deverão ser reduzidos ao mínimo indispensável para que a escola possa cumprir sua função essencial de transmitir conhecimento aos estudantes", o ESP revela tanto a expressiva falta de intimidade com a realidade dos ambientes de formação, como apresenta uma visão reducionista do papel da educação como mera transmissora de conhecimentos, visão esta que vem sendo superada há décadas, quando se percebe que a função essencial dos espaços de formação é a construção do conhecimento a partir do diálogo, numa perspectiva humanista voltada à participação consciente do sujeito de modo a transformar sua realidade social. 
Saliente-se que este PL 1.411/2015 do deputado Rogério Marinho (PSDB-RN) propõe a tipificação do crime de assédio ideológico que quer dizer, conforme o projeto, "toda prática que condicione o aluno a adotar determinado posicionamento político, partidário, ideológico ou qualquer tipo de constrangimento causado por outrem ao aluno por adotar posicionamento diverso do seu, independente de quem seja o agente" (MANHAS, 2016, p. 20), devendo-se acrescer em $1 / 3$ a pena se o agente cometer o crime dentro do estabelecimento de ensino.

Isso significa que o crime de assédio ideológico poderia ser cometido em qualquer lugar, dentro ou fora da escola, invadindo-se, supostamente, o direito de liberdade de expressão dos professores, coordenadores, orientadores, que não mais poderiam exprimir suas opiniões, posicionamentos políticos, convicções morais, religiosas, sob o risco de estarem incursos nas penas desse crime.

Dessa forma, percebe-se que o ESP atua suprimindo diversidades e instigando as desigualdades, promovendo discursos de ódio às diferenças, revelando-se uma "ameaça à vivência social e à liquidação da escola pública como espaço de formação humana, firmado nos valores da liberdade, de convívio democrático e de direito e respeito à diversidade" (FRIGOTTO, 2017, p. 17).

Aliada à concepção reducionista da educação como mera transmissora de conhecimentos, o Movimento limita a cidadania ao direito à informação, conforme trecho reproduzido em diversos PLs "entre as finalidades da educação, o preparo do educando para o exercício da cidadania. Ora, o direito de ser informado sobre os próprios direitos é uma questão de estrita cidadania" (grifo nosso).

Compreende-se, portanto, que um dos objetivos dos PLs é formar o cidadão para o exercício da cidadania, contudo, desde que não atuem nos espaços políticos, conforme se depreende do artigo 3으. III, dos PLs, quando determina que o professor "Não fará propaganda político-partidária em sala de aula, nem incitará seus alunos a participar de manifestações, atos públicos e passeatas". Ao que parece, o Movimento detém uma visão deturpada do que é cidadania, dissociando esta da participação nos espaços políticos, estabelecendo como suficiente ao exercício da cidadania o direito dos estudantes de serem informados sobre os seus próprios direitos.

Os dados demonstram que "a idéia da cidadania é uma idéia eminentemente política que não está ligada a valores universais, mas a decisões políticas (SOARES, 2004, p. 4). Dessa forma, por meio da inserção dos ideais do ESP na legislação brasileira, estará se legitimando uma nova concepção de cidadania, mas agora sem a participação ativa na política, indispensável numa democracia, em razão de que a escola não se ocupará mais de uma formação cidadã que prima pela solidariedade, participação, tolerância, conscientização política, inclusão social. O ESP, portanto, visa a uma educação servil, interessada na formação de indivíduos obedientes, cidadãos passivos, cerceando, dessa maneira, os espaços democráticos no Brasil.

Ressalte-se que esse tipo de educação eivada de neutralidade e propensa a formar cidadãos passivos representa um campo fértil para reprodução de ideologias dominantes. Daí porque a importância de possibilitar acesso ao conhecimento, priorizando não só as habilidades para ler, escrever, desenvolver cálculos, como preconiza o ESP, mas também a história das comunidades, a luta pelos direitos humanos, como forma de exercer a cidadania, uma vez que longe dessa realidade os alunos deixarão de participar das decisões que atingem seus interesses e de suas famílias, pois o debate político ficará nas mãos de poucos, perpetuando a ideologia dominante (CARREIRA, 2016).

Fica claro então nesse modelo imposto pelo ESP a concepção bancária da educação criticada por Freire

Na concepção "bancária" que estamos criticando, para a qual a educação é o ato de depositar, de transferir, de transmitir valores e conhecimentos, não se verifica nem pode verificar-se esta superação. Pelo contrário, refletindo a sociedade opressora, sendo dimensão da "cultura do silêncio", a "educação" "bancária" mantém e estimula a contradição (FREIRE, 1987, p. 34).

A superação a que Freire se refere reside no fato de que ao mesmo tempo educadores possam ser educandos e vice-versa, tendo em vista que ensinam e aprendem mutuamente. O que não é possível numa cultura em que o professor apenas ensina conteúdos vazios de contextualização e problematização, posto que é apenas transmissor de conhecimentos, desestimulando uma cultura democrática, cidadã, compromissada com a transformação social (GADOTTI, 2016). 
Ante o exposto, pode-se compreender que o ESP combate o enfrentamento de questões essenciais à promoção de princípios basilares da sociedade, como a cidadania, a democracia e a igualdade. Assim, a instituição do ESP trará graves consequências para a formação de espaços democráticos na sociedade brasileira, na medida em que, distante de uma formação cidadã, a cultura do silenciamento produzirá alunos sem criatividade, alienados, acríticos, conformados com as desigualdades da realidade social, pois em razão da falta de conhecimento, de formação política, sem consciência, não estarão empoderados ao enfrentamento.

\section{CONSIDERAÇÕES FINAIS}

Retomando a problemática que orientou esta pesquisa, a saber: Quais as perspectivas sobre democracia e cidadania no Movimento "Escola sem Partido"?, apresenta-se como pressupostos os de que ESP se traduz em uma ameaça às bases da democracia e aos fundamentos da liberdade, uma vez que direciona a cidadania aos interesses do jogo partidário, comprimindo-a ao ato de votar e ser votado.

Ainda, que castra a liberdade de cátedra e a autonomia dos professores; desmotiva os sujeitos a participarem ativamente dos espaços políticos; promovendo desigualdades ao tolher os discursos inclusivos, sobretudo de gênero e sexualidade; instigando a violência e a perseguição ao instituírem um ambiente de "caça às bruxas" nas escolas públicas brasileiras ao legitimar notificações extrajudiciais como forma de estimular a delação de professores que compartilharem suas vivências e experiências, numa tentativa de dissociar o ser político do profissional da educação.

Inspirado no Código de Defesa do Consumidor, de modo a intervir na relação ensino-aprendizagem com o suposto objetivo de proteger o estudante na condição de parte mais fraca dessa relação, o projeto do Movimento Escola sem Partido tem disseminado, desde 2004, discursos de perseguição e promoção de ódio contra os professores, acusando-os da prática de doutrinação política e ideológica, tendo em vista que, conforme o ideário do Movimento, os docentes influenciam os sujeitos em processo de formação a seguirem determinados partidos e candidatos, desequilibrando o jogo político, em favor dos competidores que detêm a simpatia do professor.

Castrando a liberdade e a autonomia docente, o ESP utiliza-se do argumento da neutralidade como uma ferramenta à promoção de valores e a ideologias de partidos políticos conservadores, bem como os vinculados a igrejas, notadamente as pentecostais. Utilizando-se ainda de um jogo semântico, ao autodenominar-se "sem partido", revela que não só tem partido, como promove discursos intolerantes, fazendo emergir o ódio, a violência e a perseguição, buscando afastar dos espaços de formação o debate sobre a diversidade, sexualidade, gênero, raça, corroborando para uma geração acrítica, porquanto pregam a reprodução de conhecimentos e mera transmissão de conteúdos, distantes de uma formação para a cidadania, para a participação democrática e voltada a modificar a realidade social do sujeito.

Constata-se ao final dessa pesquisa que as teses levantadas pelo Movimento resumem-se à mera disponibilização dessas informações em meios virtuais, sem amadurecimento e debate dos argumentos que compõem os PLs. Em outras palavras, é um debate pouco democrático para um contexto que se diz democrático. O ESP ainda justifica essa reprodução, amparado no conceito de "significante vazio" que subsidia a norma a ter conceitos mais abertos, podendo ser ajustados à realidade de cada município ou Estado por eles atingidos, com o objetivo de abranger um número maior de adeptos ao Movimento.

Verificou-se, no entanto, que o Movimento considera como tais significantes vazios conceitos como democracia, cidadania, ideologia, neutralidade, que são construções essencialmente políticas e assim sendo, o ESP intenta impor suas próprias convicções políticas e ideológicas quando, por exemplo, não permite que os professores estimulem seus alunos a participarem de espaços políticos como passeatas, manifestações e atos públicos.

Assim, embora argumentem que suas diretrizes estão em conformidade com a LDB e afinadas com uma educação cidadã, o Movimento não reconhece os espaços de formação como locais de construção da cidadania. Reiterando que estes espaços têm a função de transmitir conteúdos esvaziados de significado, estão introduzindo sua própria concepção de cidadania, mas agora sem participação popular, retirando dos alunos o direito de serem informados sobre seus direitos como exercício de estrita cidadania. 
Nessa perspectiva, a neutralidade do ensino implicaria a formação de sujeitos alienados, sem consciência do poder de transformar a realidade social na qual estão inseridos, tornando-se meros serviçais do capital. Importa, portanto, destacar que o alvo do Movimento são as escolas públicas, excluindo as escolas particulares e confessionais, sob a justificativa de que o Estado deve ser neutro e laico, contudo isso ocorre em razão de ser a escola pública acessível às classes mais populares. Sem o conhecimento, os alunos não reivindicarão seus direitos fundamentais básicos, tendo em vista que ninguém luta contra aquilo que não conhece.

\section{REFERÊNCIAS}

ALAGOAS. Assembleia Legislativa do Estado de Alagoas. Projeto de Lei Ordinária PLO 69/2015. Institui, no âmbito do sistema estadual de ensino, o Programa "Escola Livre". Disponível em: <https://sapl.al.al.leg.br/sapl_documentos/materia/64_texto_ integral>. Acesso em: set. 2017.

ALTHUSSER, Louis. Ideologia e aparelhos ideológicos do Estado. 3. ed. Lisboa: Presença, 1980.

AMAZONAS. Assembleia Legislativa do Estado do Amazonas. Projeto de Lei Ordinária PLO 102/2016. Institui, no âmbito do sistema estadual de ensino, o "Programa Escola sem Partido". Disponível em: <http://platinysoares.com.br/blog/wp-content/ uploads/2016/05/PL-016-Escola-sem-partido.pdf>. Acesso em: set. 2017.

BÁRBARA, Isabel Scrivano Martins Santa; CUNHA, Fabiana Lopes da; BICALHO, Pedro Paulo Gastalho. Escola sem partido: visibilizando racionalidades, analisando governamentalidades. In: FRIGOTTO, Gaudêncio (Org.). Escola "sem" partido: esfinge que ameaça a educação e a sociedade brasileira. Rio de Janeiro: Uerj; LPP, 2017. p. 105-120.

BARCELLOS, Ana Paula de. O direito à educação e o STF. In: SARLET, Ingo Wolfgang. SARMENTO, Daniel (Coord.). Direitos fundamentais no Supremo Tribunal Federal: balanço e crítica. Rio de Janeiro: Lumen Juris, 2011. p. 609-633.

BARDIN, Laurence. Análise de conteúdo. São Paulo: Edições 70, 2011.

BASTOS, Celso Ribeiro; MARTINS, Ives Gandra. Comentários à constituição do Brasil. São Paulo: Saraiva, 1998. 8 v.

BENEVIDES, Maria Victoria. Educação para a democracia. Lua Nova, São Paulo, n. 38, p. 223-237, 1996.

BRAIT, Daniele. Os protagonistas do ESP. In: AÇÃO EDUCATIVA ASSESSORIA PESQUISA E INFORMAÇÃO (Org.). A ideologia do movimento escola sem partido: 20 autores desmontam o discurso. São Paulo: Ação Educativa, 2016. p. 161-165.

BRASIL. Constituição (1988). Constituição da República Federativa do Brasil. Brasília, DF: Senado Federal: Centro Gráfico, 1988. . Lei no 9.394, de 20 de dezembro de 1996. Estabelece as diretrizes e bases da educação nacional. Brasília: Presidência da República, 1996.

CARREIRA, Denise. No chão da escola: conversando com famílias e profissionais da educação sobre o "escola sem partido". In: AÇÃO EDUCATIVA ASSESSORIA PESQUISA E INFORMAÇÃO (Org.). A ideologia do movimento escola sem partido: 20 autores desmontam o discurso. São Paulo: Ação Educativa, 2016. p. 125-136.

CASTRO, Carlos Roberto Siqueira. A constituinte aberta e os direitos fundamentais: ensaios sobre o constitucionalismo pós-moderno e comunitário. Rio de Janeiro: Forense, 2010.

CEARÁ. Assembleia Legislativa do Estado do Ceará. Projeto de Lei Ordinária PLO 91/2014. Institui, no âmbito do Sistema Estadual de Ensino do Ceará, o Programa "Escola sem Partido". Disponível em: <https://www2.al.ce.gov.br/legislativo/tramit2014/ pi91_14.htm>. Acesso em: set. 2017.

CRESWELL, John W. Projeto de pesquisa: métodos qualitativo, quantitativo e misto. Tradução Magda Lopes. Consultoria, supervisão e revisão técnica desta edição Dirceu da Silva. 3. ed. Porto Alegre: Artmed, 2010.

DISTRITO FEDERAL. Câmara dos Deputados. Projeto de Lei Ordinária PLO 867/2015. Altera a Lei de Diretrizes e Bases da Educação Lei no 9.394 de 20 de dezembro de 1996. Inclui, entre as diretrizes e bases da educação nacional, o "Programa Escola sem Partido".

. Câmara dos Deputados. Projeto de Lei Ordinária PLO 1.411/2015. Tipifica o crime de Assédio Ideológico e dá outras providências. Altera o Decreto-lei № 2.848, de 1940 e a Lei no 8.069, de 1990.

. Senado Federal. Projeto de Lei Ordinária PLO 193/2016. Inclui entre as diretrizes e bases da educação nacional, de que trata a Lei no 9.394, de 20 de dezembro de 1996, o “Programa Escola sem Partido". Disponível em: <https://www25.senado. leg.br/web/atividade/materias/-/materia/125666>. Acesso em: set. 2017.

. Câmara Legislativa do Distrito Federal. Projeto de Lei Ordinária PLO 53/2015. Institui, no âmbito do Distrito Federal, o Programa Escola sem Partido. 2015. Disponível em: <http://legislacao.cl.df.gov.br/Legislacao/consultaProposicao-1!53!2015!visualizar.action>. Acesso em: set. 2017.

Câmara Legislativa do Distrito Federal. Projeto de Lei Ordinária PLO 7.180/2014. Altera o art. 3o da Lei no 9.394, de 20 de dezembro de 1996, que estabelece as diretrizes e bases da educação nacional. Disponível em: <http://www.camara.gov.br/ proposicoesWeb/prop_mostrarintegra?codteor=1230836\&filename=PL+7180/2014>. Acesso em: set. 2017. 
ESPINOSA, Betty R. Solano; QUEIROZ, Felipe B. Campanuci. Breve análise sobre as redes do Escola sem Partido. In: FRIGOTTO, Gaudêncio (Org.). Escola "sem" partido: esfinge que ameaça a educação e a sociedade brasileira. Rio de Janeiro: Uerj; LPP, 2017. p. 49-62.

ESPÍRITO SANTO. Assembleia Legislativa do Estado do Espírito Santo. Projeto de Lei Ordinária PLO 250/2014. Institui, no âmbito do sistema estadual de ensino, o "Programa Escola sem Política Partidária". Disponível em: <https://s3-sa-east-1.amazonaws. com/educa caoeparticipacao-producao/wp-content/uploads/pl2502014.pdf>. Acesso em: set. 2017.

FERNANDES, Florestan. O desafio educacional. São Paulo: Cortez, 1989.

FREIRE, Paulo. Pedagogia do oprimido. 17. ed. Rio de Janeiro: Paz e Terra, 1987.

A mensagem de Paulo Freire: textos de Paulo Freire selecionados pelo Inodep. São Paulo: Nova Crítica, 1977.

. Educação como prática da liberdade. 6. ed. Rio de Janeiro: Paz e Terra, 1976.

Pedagogia da autonomia. Saberes necessários à prática educativa. 16. ed. São Paulo: Paz e Terra, 2000.

FREITAS, Maria Virgínia de. Jovens, escola democrática e proposta do "escola sem partido". In: AÇÃO EDUCATIVA ASSESSORIA PESQUISA E INFORMAÇÃO (Org.). A ideologia do movimento escola sem partido: 20 autores desmontam o discurso. São Paulo: Ação Educativa, 2016. p. 101-107.

FRIGOTTO, Gaudêncio. "Escola sem partido": imposição da mordaça aos educadores. 2016. Disponível em: <https://espacoacademico.wordpress.com/2016/06/29/escola-sem-partido-imposicao-da-mordaca-aos-educadores/>. Acesso em: 6 jun. 2017.

. A gênese das teses do Escola sem Partido: esfinge e ovo da serpente que ameaçam a sociedade e a educação. In: FRIGOTTO, Gaudêncio (Org.). Escola "sem" partido: esfinge que ameaça a educação e a sociedade brasileira. Rio de Janeiro: Uerj; LPP, 2017. p. 17-34.

GADOTTI, Moacir. A escola cidadã frente à "escola sem partido". In: AÇÃO EDUCATIVA ASSESSORIA PESQUISA E INFORMAÇÃO (Org.). A ideologia do movimento escola sem partido: 20 autores desmontam o discurso. São Paulo: Ação Educativa, 2016. p. 149-160.

. Escola cidadã. São Paulo: Cortez, 1992.

GIL, Antonio Carlos. Método e técnicas de pesquisa social. 6. ed. São Paulo: Atlas, 2008.

GOIÁs. Assembleia Legislativa do Estado de Goiás. Projeto de Lei Ordinária PLO 293/2014. Cria, no âmbito do sistema de ensino do Estado de Goiás, o "programa escola sem partido" que dispõe sobre os deveres dos professores no exercício de sua profissão em todo território do Estado de Goiás na forma que especifica, e dá outras providências. Disponível em: <https://s3sa-east-1.amazonaws.com/educacaoeparticipacao-producao/wp-content/uploa ds/processo_2014002861_goias.pdf>. Acesso em: set. 2017.

IOSCHPE, Gustavo. A neutralidade como dever. 2008. Disponível em: <http://escolasemp artido.org/artigos/211-a-neutralidade-como-dever> Acesso em: 15 ago. 2017.

LAKATOS, Eva Maria; MARCONI, Marina de Andrade. Fundamentos de metodologia científica. 5. ed. São Paulo: Atlas, 2003.

MANHAS, Cleomar. Nada mais ideológico que "escola sem partido". In: AÇÃO EDUCATIVA ASSESSORIA PESQUISA E INFORMAÇÃO (Org.). A ideologia do movimento escola sem partido: 20 autores desmontam o discurso. São Paulo: Ação Educativa, 2016. p. 15-22.

MATTOS, Amana. et al. Educação e liberdade: apontamentos para um bom combate ao Projeto de Lei Escola sem Partido. In: FRIGOTTO, Gaudêncio (Org.). Escola "sem" partido: esfinge que ameaça a educação e a sociedade brasileira. Rio de Janeiro: Uerj; LPP, 2017. p. 87-104.

MELLO, José Celso de. Constituição Federal anotada. São Paulo: Saraiva, 1984.

ORGANIZAÇÃO DAS NAÇÕES UNIDAS PARA A EDUCAÇÃO, A CIÊNCIA E A CULTURA (Unesco). Um tesouro a descobrir. Relatório para a Unesco da Comissão Internacional para o Século XXI. Destaques Unesco, 2010.

no Brasil, 2005.

Convenção sobre a proteção e promoção da diversidade das expressões culturais. Brasília: Representação da Unesco

ORGANIZAÇÃO DOS ESTADOS AMERICANOS. (OEA) Convenção Americana de Direitos Humanos - Pacto de San José de Costa Rica. Costa Rica: OEA, 1969.

PERNAMBUCO. Assembleia Legislativa do Estado de Pernambuco. Projeto de Lei Ordinária PLO 823/2016. Dispõe sobre princípios, vedações e deveres no âmbito do sistema estadual de ensino e dá outras providências. Disponível em: <http://www. alepe.pe.gov.br/pro posicao-texto-ompleto/?docid=A99C8ECOFCD5202A03257FAF0066E37A>. Acesso em: set. 2017.

RATIER, Rodrigo. 14 perguntas e respostas sobre o "escola sem partido". In: AÇÃO EDUCATIVA ASSESSORIA PESQUISA E INFORMAÇÃO (Org.). A ideologia do movimento escola sem partido: 20 autores desmontam o discurso. São Paulo: Ação Educativa, 2016. p. 29-42.

RIBEIRO, Renato Janine. Escola Sem Partido preocupa por questionar a transmissão dos saberes. Disponível em: <http://www. cartaeducacao.com.br/entrevistas/escola-sem-partido-preocupa-por-questionar-a-transmissao-dos-saberes-afirma-janine/>. Acesso em: 10 jun. 2017. 
RIO DE JANEIRO. Assembleia Legislativa do Estado do Rio de Janeiro. Projeto de Lei Ordinária PLO 2974/2014. Cria, no âmbito do sistema de ensino do Estado do Rio de Janeiro, o "Programa Escola Sem Partido". Disponível em: <http://alerjln1.alerj. rj.gov.br/scpro1115.nsf/e4bb858a5b3d42e383256cee006ab66a/45741a7e2ccdc50a83257c980062a2c2?0penDocument>. Acesso em: set. 2017.

SAKAMOTO, Leonardo. "Escola sem partido": doutrinação comunista, coelho da páscoa e papai Noel. In: AÇÃO EDUCATIVA ASSESSORIA PESQUISA E INFORMAÇÃO (Org.). A ideologia do movimento escola sem partido: 20 autores desmontam o discurso. Ação Educativa Assessoria Pesquisa e Informação (Org.). São Paulo: Ação Educativa, 2016. p. 11-14.

SÃO PAULO. Assembleia Legislativa do Estado de São Paulo. Projeto de Lei Ordinária PLO 960/2014. Institui, no âmbito do Sistema Estadual de Ensino, o “Programa Escola sem Partido”. Disponível em:<https://www.al.sp.gov.br/propositura/?id=1215641>. Acesso em set. 2017.

SILVA, José Afonso da. Comentário contextual à Constituição. 7. ed. São Paulo: Malheiros, 2010.

SILVA, Tomaz Tadeu. Documentos de identidade: uma introdução às teorias do currículo. 3. ed. Belo Horizonte: Autêntica, 2013. SOARES, Maria Victoria Benevides. Cidadania e direitos humanos. In: CARVALHO, J. S. (Org.). Educação, cidadania e direitos humanos. Petrópolis: Vozes, 2004.

VERGARA, Sylvia Constant. Métodos de pesquisa em administração. 5. ed. São Paulo: Atlas, 2012. 